\title{
The Breaking of the 'Great Australian Silence': How and Why the Writing of Indigenous Australian History has Changed over the Last 40 Years
}

\author{
Caroline Beasley
}

\section{Abstract}

Australian history has not always recognised the traditional Indigenous occupants of the country. For various reasons, including prevailing ideas about race, Indigenous peoples were excluded from Australian history. Anthropologist WEH Stanner's 1968 Boyer Lectures called historians to ensure this pervasive forgetfulness of the Indigenous population ceased, a process already under way when the lectures were delivered. The lectures had their intended effect of further encouraging the historical revision that subsequently altered the foundations of Australian history by creating a new field: Indigenous Australian history. These changes in historiography occurred gradually, and included many historians. The prevailing social and cultural forces of the time were also instrumental in aiding this revision, and included the 1967 referendum and subsequent land rights movement, societal tensions over the bicentenary celebrations in 1988, the High Court decisions of Mabo and Wik, as well as the political leadership of the time with which this field became intertwined. Ultimately Indigenous Australians moved from being a 'melancholy footnote' in Australian history, to occupying a central place in the historiography.

\section{Introduction}

It is not just a matter of attaching Aboriginal history to the back left hand corner of the old homestead or of even glassing in the back verandah. The changes will ultimately have to be far more radical - a new floor perhaps, even new foundations. ${ }^{1}$

1 Henry Reynolds, 'History from the Frontier', in Bain Attwood (ed.), In the Age of Mabo: History, Aborigines and Australia, Allen and Unwin, St Leonards, 1996, p. xv. 
The ANU Undergraduate Research Journal

Henry Reynolds

The last 40 years have been a time of great change for the discipline of Indigenous Australian history. As Reynolds's remark suggests, this change required a dramatic shift in how Australian history was conceptualised, such that 'new foundations' were mandatory for the traditional Australian historical discourse from which Indigenous Australians were excluded. Following anthropologist WEH Stanner's 1968 Boyer Lectures, the scene was set for further historical revision of traditional ideas of Australia's past, with Indigenous Australians in mind. As Stanner put it, 'the native question is rising into great importance, the melancholy footnote is turning into a whole chapter of Australian history, and the codicil is becoming a major theme in the Australian story'. ${ }^{2}$

Many historians were part of this revisionism, which has evolved significantly since the 1970s, occurring incrementally and not without criticism and rerevision. These changes in the Australian historical discourse leading to greater inclusion of Indigenous Australians can be attributed to several factors including the political disposition of the time, landmark constitutional and legal changes such as the 1967 referendum, the land rights movement, public tensions over the bicentenary celebrations in 1988 and the Mabo and Wik decisions concerning Indigenous land rights, as well as the desire to create a national identity. ${ }^{3}$ The changes in Australian historical scholarship that have occurred over the last 40 years resulted in the stories of Indigenous people, and the Indigenous perspective, being increasingly included in the Australian historical narrative. This essay will focus on how ideas of Indigenous Australian history changed, before considering the factors contributing to why these changes occurred. First, however, it is necessary to explore what the phrase 'Indigenous Australian history' means.

\section{What is Indigenous Australian History?}

History itself is a primarily European discourse ${ }^{4}$ the nature of which perpetuates the exclusion of Indigenous people from early Australian narratives. ${ }^{5}$ The thendominant racial thought encouraged colonisers to understand Indigenous people

\footnotetext{
2 WEH Stanner, The Dreaming and Other Essays, Black Inc. Agenda, Melbourne, 2009, p. 176. 'Melancholy footnote' and 'codicil' were terms that had previously been used by historians and anthropologists to describe the status of Indigenous peoples in Australian history. See, for example, JA La Nauze, 'The Study of Australian History 1929-1959', Historical Studies Australia and New Zealand, vol. 9, no. 33, 1959, p. 11.

3 Mabov Queensland (No. 2) (1992) 175 CLR 1; The Wik Peoples $v$ Queensland (1996) 141 ALR 129.

4 Attwood, 'Introduction, the Past as Future: Aborigines, Australia and the (Dis)course of History', in Attwood (ed.), Age of Mabo, p. viii.

5 Jackie Huggins, Sister Girl: The Writing of Aboriginal Activist and Historian Jackie Huggins, University of Queensland Press, 1998, p. 2.
} 
as 'preliterate' and their society as 'prehistorical' ${ }^{6}$ This led to further affirmation of their exclusion from Australian history as they were unable to be the subjects of history. ${ }^{7}$ Any unfamiliar aspects of Indigenous life were assigned to 'the fickle, wavering disposition of all savages'.$^{8}$ Accordingly, the main subjects of traditional Australian history were the British, conceptualised as brave and resourceful pioneers who peacefully colonised the harsh land of Australia. ${ }^{9}$

Given the difference between Indigenous and European cultures, a prominent issue for Indigenous history is the question of who is best placed to write it: ${ }^{10}$ if Indigenous history is primarily written by European historians, can it still be considered Indigenous history given its concern with Aboriginal experience? ${ }^{11}$ Some Indigenous writers, such as Jill Milroy, have labelled this dichotomy as the difference between writing Indigenous history, and history about Indigenous people. ${ }^{12}$ Although Indigenous people can offer unique insights into their history, some European historians have been active in the propagation of Indigenous history. These writers have often explicitly stated that their work is not an attempt to speak on behalf of Indigenous people, but rather a European interpretation, while others have made efforts to use Indigenous oral histories as sources to inform their work. ${ }^{13}$ As such, this essay defines Indigenous Australian history as those historical discourses in which Indigenous people are subjects, written either by Indigenous or non-Indigenous historians. It is worth noting that much of the scholarship in this field was created at a time when the field was known as Australian Aboriginal history. Indeed a prominent journal in this field is titled Aboriginal History and it aims to emphasise 'not only ... Aboriginal people as subjects and actors but Aboriginal perceptions and perspectives as well'. ${ }^{14}$ As such the terms 'Indigenous' and 'Aboriginal' are used interchangeably throughout the essay. ${ }^{15}$

\footnotetext{
6 Lorenzo Veracini, 'A Prehistory of Australia's History Wars: The Evolution of Aboriginal History During the 1970s and 1980s', Australian Journal of Politics and History, vol. 52, no. 3, 2006, p. 440.

7 Judy Iseke-Barnes, 'Living and Writing Indigenous Spiritual Resistance', Journal of Intercultural Studies, vol, 24, no. 3, 2003, p. 214.

8 Stanner, The Dreaming, p. 93.

9 Attwood, Telling the Truth About Aboriginal History, Allen and Unwin, Crows Nest, 2005, pp. 14-15.

10 Huggins, Sister Girl, p. 1.

11 ibid., p. 2.

12 Peggy Brock, 'Skirmishes in Aboriginal History', Aboriginal History, vol. 28, 2004, p. 208.

13 Henry Reynolds, The Other Side of the Frontier: Aboriginal Resistance to the European Invasion of Australia, Penguin, Ringwood, 1982, p. 1; Ann McGrath, Born in the Cattle: Aborigines in Cattle Country, Allen and Unwin, Sydney, 1987.

14 Attwood, 'The Founding of Aboriginal History and the forming of Aboriginal History' Aboriginal History, vol. 36, 2012, p. 136.

15 The author of this paper is a European Australian.
} 


\section{Changes in Indigenous Australian History}

In the 'most consequential lecture ever broadcast on the $\mathrm{ABC}^{\prime}{ }^{16}$ Stanner highlighted how the Indigenous experience of colonisation and its effects had been increasingly omitted from the Australian historical discourse as developed in the twentieth century — the 'great Australian silence'. ${ }^{17}$ This called historians to action:

what may have begun as a simple forgetting of other possible views turned into a habit and over time into something like a cult of forgetfulness practiced on a national scale. ${ }^{18}$

This 'cult' was so pervasive that Australians struggled to keep the traditional occupants of the land in mind, even when it was important to do so, thus perpetuating the 'great Australian silence' ${ }^{19}$ At the time of his Boyer Lectures, however, Stanner noted that the Indigenous past was returning to public awareness. ${ }^{20}$ Indeed, since these lectures, historians have begun to create a 'new Australian history', ${ }^{21}$ with 'many voices ... fill[ing] out the space once claimed by [the] great Australian silence' ${ }^{22}$ Since Stanner's lecture, the process of change in Indigenous history has occurred incrementally, recognising different features of the Indigenous experience over time. ${ }^{23}$

In the early 1970s historians began to write 'social history', which saw invasion as the main theme of colonisation, as opposed to the previously 'peaceful' arrival of the British that underscored traditional colonial history. The perceived incompatibility between Indigenous and European cultures was clear, especially surrounding land use, and there was an understanding that violence on the frontier had caused the British destruction of Indigenous societies. ${ }^{24}$ The work of this period saw Indigenous people as victims, which was a shift from the traditional historical discourse of 'forgetfulness' of the Indigenous population. ${ }^{25}$

\footnotetext{
16 Robert Manne, 'Introduction', in Manne (ed.), Whitewash: On Keith Windschuttle's Fabrication of Aboriginal History, Black Inc. Agenda, Melbourne, 2003, p. 1.

17 ibid.

18 Stanner, The Dreaming, p. 189.

19 ibid.

20 Attwood, Telling the Truth, p. 17.

21 Attwood, 'Introduction', in Attwood (ed.), Age of Mabo, p. xv.

22 Henry Reynolds, Why Weren't We Told? A Personal Search for the Truth about our History, Penguin Books Australia, Ringwood, 1999, p. 257.

23 Veracini, 'A Prehistory', p. 439.

24 Attwood and Foster, 'Introduction', in Attwood and Foster (eds), Frontier Conflict, p. 4, 5; Veracini, 'Of a "Contested Ground" and an "Indelible Stain": A Difficult Reconciliation between Australia and its Aboriginal History during the 1990s and 2000s', Aboriginal History, vol. 27, 2003, p. 225.

25 Veracini, 'A Prehistory', pp. 441-42. CD Rowley was an important writer in this movement whose work predates Stanner's lectures. By 1969 he had already advocated an Indigenous perspective in Aboriginals in Australian Society and, in 1972, published The Destruction of Aboriginal Society, which is an important example of the 'social history' of the 1970s.
} 
In the late 1970s historians began to focus more on the scope of Indigenous resistance to the colonising force and the frontier was seen as 'contested' ${ }^{26}$ This also involved consideration of Indigenous perspectives, as pioneered by Reynolds in The Other Side of the Frontier (1981). ${ }^{27}$ Indigenous authors also began to publish their own work at this time and this represented a significant change in the historiographical landscape, particularly given the personal nature of the stories and their basis in oral histories. ${ }^{28}$

Influenced by Reynolds's consideration of alternative perspectives, 1980s scholarship began to approach Indigenous oral sources as supplements to the written records. ${ }^{29}$ This era was also characterised by exploration of Indigenous agency. ${ }^{30}$ Ann McGrath's research, which exemplified this through its focus on Aboriginal employment in the Northern Territory cattle industry, encouraged historical exploration of themes other than frontier violence. ${ }^{31}$

More recently, scholarship on the nature of Australian frontiers has declined in favour of exploration of the possibility of genocide, as well as representations of Aboriginality. ${ }^{32}$ This has seen conservative historians mount an attack on the 'black armband' view of history. The term 'black armband history' was coined by historian Geoffrey Blainey in 1993 to describe history that focuses on the more sombre and negative aspects of Australia's past, such as the treatment of Aboriginal people, rather than narratives of national achievement. According to Blainey, this approach was motivated by a desire to be politically correct, rather than by truth. ${ }^{33}$ Proponents of Blainey's view advocated a return to traditional views of Australian history, a view labelled by revisionist historians as 'white blindfold history'. The aim of this rerevision was to restore faith in the good character of the nation created by the British. ${ }^{34}$ This re-revision was inherently political.

Overall, since Stanner's 1968 lectures, the great Australian silence has been filled with many voices, which satisfied Stanner's call for an emphasis on Indigenous experience since colonisation. ${ }^{35}$ Indigenous people moved from 'footnote' to the forefront of Australian history, challenging its foundations and its structure.

\footnotetext{
26 Veracini, “'Contested Ground”', p. 225; Veracini, 'A Prehistory', p. 443.

27 Attwood and Foster, 'Introduction', in Attwood and Foster (eds), Frontier Conflict, pp. 6-7; Attwood,

'Historiography on the Australian Frontier', in Attwood and Foster (eds), Frontier Conflict, p. 171.

28 Brock, 'Skirmishes', p. 211.

29 Attwood and Foster, 'Introduction', in Attwood and Foster (eds), Frontier Conflict, pp. 8-9.

30 Veracini, 'A Prehistory', p. 448.

31 ibid.; Attwood, 'Historiography of the Australian Frontier', in Attwood and Foster (eds), Frontier Conflict, p. 172; Ann McGrath, Born in the cattle: Aborigines in cattle country, Allen and Unwin, Sydney, 1987.

32 Attwood and Foster 'Introduction', in Attwood and Foster (eds), Frontier Conflict, p. 10.

33 Brock, 'Skirmishes', p. 219.

34 ibid., p. 207.

35 Attwood, Telling the Truth, p. 42.
} 


\section{Why has Indigenous Australian History Changed?}

As Indigenous Australians became more prominent in historical discourses, these histories were increasingly linked with aspects of public life. The policies of contemporary governments, as well as political and legal endorsements of certain historical perspectives, contributed to the changes in Indigenous Australian history that have occurred since 1968. This was particularly true in the 1990s, when history's increased politicisation ensured the 'new foundations' referred to by Reynolds were established within the Australian psyche. ${ }^{36}$

After the successful 1967 referendum which removed some constitutional discrimination against Indigenous peoples, Indigenous people were subject to Commonwealth legislation and able to be included in the census, a change that began the slow process of increasing legal rights and changing public perception. Reynolds vividly illustrated the pace of this change in a haunting depiction of a scene at a Palm Island jail in 1969, where two Indigenous schoolgirls were held as punishment for answering back to their kindergarten teacher. ${ }^{37}$ The referendum movement more broadly was significant as it resulted in a large section of the Australian community - over 90 per cent - mobilising in favour of the removal of discrimination against Indigenous peoples. ${ }^{38}$ The success of the referendum was also symbolically significant for Australia on an international level as, by the 1960s, numerous other settler societies had recognised equal rights for colonised peoples. ${ }^{39}$ Australia's Indigenous peoples were able to seize the momentum embodied in the referendum movement to start a more organised and more widespread land rights movement. The Tent Embassy, an enduring symbol of this struggle, was established in Canberra in 1972 and aimed to secure Indigenous title to land, mining royalties and other compensation, as well as illustrating symbolic sovereignty over the land. ${ }^{40}$ The end of discriminatory immigration and assimilation policies, which detrimentally affected Indigenous people, occurred concurrently with the slow beginning of Australian historical revision in the early 1970s. This was encouraged by the prominence of the subsequent land rights movement. ${ }^{41}$

\footnotetext{
36 Reynolds, 'History from the Frontier', in Attwood (ed.), Age of Mabo, p. xv.

37 Reynolds, Why Weren't We Told?, p. 9.

38 ibid.

39 Attwood, Telling the Truth, p. 20.

40 'Aboriginal Embassy Land Rights Policy "5 Point Policy"', in Attwood and Markus, Struggle for Aboriginal Rights, p. 257-58; Kathy Lothian, 'Moving Blackwards: Black Power and the Aborignal Embassy', in Ingereth MacFarlane and Mark Hannah (eds), Transgressions: Critical Australian Indigenous Histories, Aboriginal History Monograph 16, ANU E Press, Canberra, 2007, p. 22.

41 Manne, 'Introduction' in Manne (ed.), Whitewash, p. 2.
} 
The notion of national identity is rooted in history, and the country's or individual's place within it. ${ }^{42}$ Traditionally, the Australian identity was defined by 'Britishness', but following World War II, this identity was challenged. ${ }^{43}$ Britain's decision in the early 1960s to focus on its economic ties with Europe, when it applied — albeit unsuccessfully — to join the European Economic Community, ${ }^{44}$ increased colonial challenges to imperial rule. ${ }^{45}$ Changes in Australian immigration policies and increasingly interlinked cultures created by global economic practices gradually led to a desire to redefine 'Australianness' ${ }^{46}$ White Australia now sometimes sought to differentiate itself by drawing on notions of Aboriginality and ancientness. ${ }^{47}$ The increased desire to appropriate Aboriginality for the purposes of national identity stemmed from scholarly revision of traditional notions of history, archaeological research that was pushing the original Aboriginal occupation of the continent back thousands of years from the date previously identified, and recognition in other settler societies of Indigenous rights. ${ }^{48}$ The increased prominence of Indigenous culture led to more widespread acceptance of, and even reverence for, Indigenous perspectives, which - while not reflecting negatively on all aspects of British colonisation — was demonstrated by changes in contemporary Australian historical discourses. ${ }^{49}$

The commemoration of the bicentenary of Australian settlement in 1988 saw the beginnings of a re-revision of Indigenous Australian history and its intertwining with national politics, which climaxed in the years of John Howard's Liberal government. In 1980 Prime Minister Malcolm Fraser created the Bicentennial Authority to determine the method of celebrating, advocating that the authority take a 'warts and all approach' to selecting ways to represent Australia's past. ${ }^{50}$ The Uniting Church and other groups opposed a Britishcentric commemoration of this occasion, alleging that this would represent 'the destruction of Aboriginal society' ${ }^{51}$ The attempts of the authority to address the concerns of every group in Australian society in an inclusive way led to claims from conservative historians that they were trying to create 'a guilt industry', which was disrespectful to Australia's British past. ${ }^{52}$ The tension between the

\footnotetext{
42 ibid., p. 30.

43 Attwood, 'Introduction', in Attwood (ed.), Age of Mabo, p. xxiv.

44 Stuart Ward, Australia and the British Embrace: The Demise of the Imperial Ideal, Melbourne University Press, 2001.

45 ibid., p. 20.

46 Attwood, 'Introduction', in Attwood (ed.), Age of Mabo, p. xxiv.

47 ibid., p. xxiii.

48 Attwood, Telling the Truth, p. 20.

49 Attwood, 'Introduction', in Attwood (ed.), Age of Mabo, p. xxxvii.

50 Stuart Macintyre and Anna Clark, The History Wars, Melbourne University Press, Carlton, 2003, p. 97.

51 ibid., p. 98.

52 ibid., p. 109.
} 
dramatic revision of Indigenous Australian history by Reynolds and others and the re-revision offered by conservative historians, was established and continued into the future following 1988.

The 1992 Mabo case and the Wik case in 1996 established native title land rights for Indigenous people, and overturned the key legal doctrine of terra nullius on which Australia's colonisation was based. ${ }^{53}$ This doctrine provided that in 1788 Australia was a land belonging to no one, despite the resident Indigenous population, enabling the British to claim the land and creating a 'lawless terrain' of subsequent relations. ${ }^{54}$ The role of Mabo and, in particular, the judgment of Justice Deane and Justice Gaudron had ramifications for subsequent historical scholarship, since it clearly established the legal status of Indigenous people since $1788 .{ }^{55}$ Indeed, the dispossession of Indigenous land and heritage that had occurred after was described in the joint judgment, which relied heavily on historical work undertaken by historians, such as Reynolds, as 'a national legacy of unutterable shame'. ${ }^{56}$ The Wik case explicitly established that native title could exist on land that was the subject of a pastoral lease. ${ }^{57}$ The two cases led to an increase in writing of local histories, and emphasis on Indigenous agency as part of the investigation of communities' ties to land to prove native title. ${ }^{58}$ The legal changes that resulted from Mabo and Wik also encouraged increased politicisation of history due to the immense challenges posed to traditional notions of history, and thus to Australian nationhood and identity. ${ }^{59}$

The relationship between historical scholarship and political shifts became more explicit in the 1990s following Mabo. ${ }^{60}$ As Labor Prime Minister in the 1990s, Paul Keating illustrated his support of the revisionist view of Indigenous Australian history, and the finding in Mabo, in a speech at Redfern Park, which was written by his speechwriter, historian Don Watson. The speech recognised, and called upon the nation to recognise, the other side of much of Australia's history since colonisation:

it was we who did the dispossessing. We took the traditional lands and smashed the traditional way of life. We brought the diseases. The alcohol. We committed the murders. We took the children from their mothers. We practised discrimination and exclusion ... ${ }^{61}$

\footnotetext{
53 Veracini, “"Contested Ground"”, p. 226.

54 ibid.

55 Veracini, “'Contested Ground"', p. 226; Veracini, 'A Prehistory', p. 444.

56 Mabo v Queensland [no 2] (1992) 175 CLR 1, 104.

57 Wik Peoples v Queensland (1996) 187 CLR 1.

58 Veracini, "“Contested Ground"', p. 226.

59 Attwood, 'Mabo, Australia and the End of History', in Attwood (ed.), Age of Mabo, p. 100.

60 Veracini, “"Contested Ground"', p. 224.

61 Redfern Park Speech (Year for the World's Indigenous People), Prime Minister Paul Keating, 10 December 1992, <http://antar.org.au/sites/default/files/paul_keating_speech_transcript.pdf >.
} 
This explicit endorsement of the revisionist view, which amounted to an apology for past injustices committed by Europeans against Indigenous people, met its ideological and political opponent in the Howard government, elected in 1996. Howard publicly used Australian history as a 'political weapon', which due to his public status, had a strong impact on perceptions of Indigenous Australian history. ${ }^{62}$ Howard condemned the 'politically correct' revisionist historians or the 'black armband brigade' — because he believed they postulated a version of history which made Australians ashamed of their past. ${ }^{63}$ Strongly advocating the return of patriotism, ${ }^{64}$ Howard stated that the Australian nation should not have to apologise for the actions of their ancestors, and laid blame on the revisionist historians for labelling the work of British settlers as insignificant. ${ }^{65}$ This reignited some of the historical debates that had occurred around the celebration of the bicentenary of Australian settlement a decade earlier. Howard's advocacy of the single, patriotic, traditional narrative of Australia, which had rigorously defined perceptions of Indigenous sovereignty and status, led to his indirect support of the conservative historians through public print media. Conservative magazine Quadrant launched several campaigns in accordance with Howard's 'white blindfold' view. ${ }^{66}$ The historian Keith Windschuttle was heavily involved in this and was often labelled as 'Howard's historian' ${ }^{67}$ His work, which sought to dispel the 'myths' advocated by revisionist historians in the field of Indigenous Australian history, and pushed for a return to the 'traditional' version of Australian history, precipitated a historiographical battle known as the 'history wars' ${ }^{68}$ Despite some serious public consideration of Windschuttle's points, ${ }^{69}$ the 'black armband' view remained ingrained in the national consciousness, and was not easily forgotten. ${ }^{70}$ As such the narratives of denialism which became prominent during this period and represented a shift away from the histories published since 1968, were considered, but not in such a way as to create a new orthodoxy.

Following Mabo, Indigenous dispossession became a recognised theme in Australian history and, as such, was a key part of the Australian Human Rights and Equal Opportunity Commission's (HREOC) 1997 Bringing Them Home report on the Stolen Generations. ${ }^{71}$ The report relied on testimonies from individuals affected by child-removal policies, illustrating the importance of memory and Indigenous oral histories in creating history, despite condemnation of these

62 Attwood, Telling the Truth, p. 32.

63 Attwood and Foster 'Introduction', in Attwood and Foster (eds), Frontier Conflict, p. 13.

64 Attwood, Telling the Truth, p. 34.

65 Attwood and Foster 'Introduction', in Attwood and Foster (eds), Frontier Conflict, p. 14.

66 Manne, 'Introduction', in Manne (ed.) Whitewash, p. 5.

67 A. Dirk Moses, 'Revisionism and Denial', in Manne (ed.), Whitewash, p. 352.

68 Brock 'Skirmishes', p. 207.

69 Manne, 'Introduction', in Manne (ed.) Whitewash, p. 7.

70 Dirk Moses, 'Revisionism', p. 351.

71 Veracini, "“Contested Ground"', p. 233. 
'sources' by the Howard government. ${ }^{72}$ The Bringing Them Home report is another example of the politicisation of Indigenous Australian history, and the effect this has had on the public. A key recommendation of the report was an official government apology to the members of the Stolen Generations, which Howard refused to make. Yet, due to the prominence of Indigenous history in public life, this decision was widely condemned. ${ }^{73}$ The public condemnation of Howard's decision not to apologise to Australia's Indigenous people illustrates clearly the changes that occurred in the field of Indigenous Australian history since 1968 - the new foundations for the history of Australia were now firmly in place.

\section{Conclusion}

This essay has illustrated the changes in Indigenous Australian history and why they have occurred over the last 40 or so years, from when Indigenous people were largely forgotten in the Australian historical discourse, to their essential presence in notions of Australian identity. Concomitantly, legal and political changes, including the 1967 referendum, subsequent land rights movement and High Court decisions, ensured that the historical changes were reflected in policy and in the settler Australian psyche, where the presence of Indigenous Australians as subjects and writers of history is now a permanent feature. This permanency is encouraged by the myriad alternative sources from which to gain historical knowledge, including novels, radio, art and songs. The increased democratisation of Indigenous Australian history is especially important; due to the increasing numbers of Indigenous and non-Indigenous contributors, consumers of history have a way to understand historical events from many perspectives, something that is likely to characterise the field of Indigenous Australian history into the future and facilitate its further expansion. ${ }^{74}$

\section{Bibliography}

Attwood, Bain, 'Introduction: The Past as Future: Aborigines, Australia and the (Dis)course of History', in Attwood (ed.), In the Age of Mabo: History, Aborigines and Australia, Allen and Unwin, St Leonards, 1996.

-, 'Mabo, Australia and the End of History', in Attwood (ed.), In the Age of Mabo: History, Aborigines and Australia, Allen and Unwin, St Leonards, 1996.

72 Attwood, Telling the Truth, p. 51.

73 Manne, 'Introduction' in Manne (ed.) Whitewash, p. 4.

74 Attwood and Foster 'Introduction', in Attwood and Foster (eds), Frontier Conflict, pp. 20-21. 
- 'Historiography on the Australian Frontier', in Attwood and SG Foster (eds), Frontier Conflict: The Australian Experience, National Museum of Australia, Canberra, 2003.

- Telling The Truth About Aboriginal History, Allen and Unwin, Crows Nest, 2005.

Attwood, Bain. "The Founding of Aboriginal History and the forming of Aboriginal History" Aboriginal History, vol. 36, 2012, pp. 119-171.

Attwood, Bain and Foster, SG, 'Introduction', in Attwood and Foster (eds), Frontier Conflict: The Australian Experience, National Museum of Australia, Canberra, 2003.

Attwood, Bain and Markus, Andrew. The Struggle for Aboriginal Rights: A documentary history, Allen \& Unwin, St Leonards, 1999.

Brock, Peggy. 'Skirmishes in Aboriginal History', Aboriginal History, vol. 28, 2004, pp. 207-25.

Clendinnen, Inga. Boyer Lectures 1999: True Stories, ABC Books, Sydney, 1999.

—_ 'The History Question: Who Owns the Past?' Quarterly Essay, no. 23, 2006.

Davidson, Robyn, 'No Fixed Address: Nomads and the Fate of the Planet', Quarterly Essay, no. 24, 2006.

Dirk Moses, A.. 'Revisionism and Denial', in Manne, Robert (ed), Whitewash: on Keith Windschuttle's Fabrication of Aboriginal History. Black Inc. Agenda, Melbourne, 2003.

Huggins, Jackie, Sister Girl: The Writing of Aboriginal Activist and Historian Jackie Huggins, University of Queensland Press, 1998.

Iseke-Barnes, Judy, 'Living and Writing Indigenous Spiritual Resistance', Journal of Intercultural Studies, vol. 24, no. 3, 2003, pp. 211-35.

- 'Introduction: Culture Wars', in Michele Grossman (ed.), Blacklines, Melbourne University Press, 2003.

Langton, Marcia, 'Anthropology, Politics and the Changing World of Aboriginal Australians', Anthropological Forum, vol. 21, 2011, pp. 1-22.

La Nauze, J. A.. “The Study of Australian History 1929-1959" Historical Studies Australia and New Zealand, vol. 9 no. 33, 1959, p. 11. 
The ANU Undergraduate Research Journal

Lothian, Kathy. 'Moving Blackwards: Black Power and the Aborignal Embassy', in MacFarlane, Ingereth and Hannah, Mark (eds). Transgressions: critical Australian Indigenous histories, Aboriginal History Monograph 16, ANU E Press, Canberra, 2007.

Macintyre, Stuart and Clark, Anna, The History Wars, Melbourne University Press, Carlton, 2003.

Manne, Robert, 'Introduction', in Robert Manne, (ed.), Whitewash: on Keith Windschuttle's Fabrication of Aboriginal History, Black Inc. Agenda, Melbourne, 2003.

McGrath, Ann, Born in the Cattle: Aborigines in Cattle Country, Allen and Unwin, Sydney, 1987.

McKenna, Mark, Looking for Blackfellas' Point: An Australian History of Place, University of New South Wales Press, Sydney, 2002.

Morton, John, 'Aboriginality, Mabo and the Republic: Indigenising Australia', in Bain Attwood (ed.), In the Age of Mabo: History, Aborigines and Australia, Allen and Unwin, St Leonards, 1996.

Mowaljarlai, David and Malnic, Jutta, Yorro Yorro: Spirit of the Kimberley, Magabala Books Aboriginal Corporation, Broome, 1993.

Redfern Park Speech (Year for the World's Indigenous People), Prime Minister Paul Keating, 10 December 1992.

Reynolds, Henry, The Other Side of the Frontier: Aboriginal Resistance to the European Invasion of Australia, Penguin, Ringwood, 1982.

- Frontier: Aborigines, Settlers and Land, Allen and Unwin, Sydney, 1987.

- ' 'History from the Frontier', in Bain Attwood (ed.), In the Age of Mabo: History, Aborigines and Australia, Allen and Unwin, St Leonards, 1996.

- Why Weren't We Told? A Personal Search for the Truth about our History, Penguin Books Australia, Ringwood, 1999.

Rowley, C. D.. Aboriginals in Australian Society. The Australian National University, Canberra, 1969.

Rowley, C. D.. The Destruction of Aboriginal Society. Penguin Books Australia, Ringwood, 1983.

Stanner, WEH, The Dreaming and Other Essays, Black Inc. Agenda, Melbourne, 2009. 
Ward, Stuart, Australia and the British Embrace: The Demise of the Imperial Ideal, Melbourne University Press, Melbourne, 2001.

Veracini, Lorenzo. 'A Prehistory of Australia's History Wars: The Evolution of Aboriginal History During the 1970s and 1980s', Australian Journal of Politics and History, vol. 52, no. 3, 2006, pp. 439-54.

- "Of a "Contested Ground" and an "Indelible Stain": A Difficult Reconciliation between Australia and its Aboriginal History during the 1990s and 2000s', Aboriginal History, vol. 27, 2003, pp. 224-39. 
This text taken from The ANU Undergraduate Research Journal Volume Five 2013, published 2014 by ANU Press, The Australian National University, Canberra, Australia. 